Original Research Paper

\title{
A Study on Public Relations Performance Evaluation (PRPE) Model to Accelerate Public Relations Practice at Universities in Bangladesh
}

\author{
${ }^{1}$ Tahmina Sultana, ${ }^{2}$ Muhammad Kawsar Mahmud and ${ }^{3}$ Taha Husain \\ ${ }^{1}$ Lecturer, Department of Business Administration in Management Studies, Bangladesh University of Professionals, Dhaka \\ ${ }^{2}$ Officer Department of Public Relations, Information and Publications, Bangladesh University of Professionals, Dhaka \\ ${ }^{3}$ Research Fellow, Wholistic Integration Dhaka, Bangladesh
}

Article history
Received: 14-06-2019
Revised: 02-09-2019
Accepted: 23-10-2019
Corresponding Author:
Taha Husain
MSS \& BSS from the
Department of Peace and
Conflict Studies, Dhaka
University, Bangladesh. And
Research Fellow, Wholistic
Integration Dhaka, Bangladesh
Email: ahmthusain@gmail.com

\begin{abstract}
Public Relations (PR) has been demarcated as an essential apparatus in the modern era that contributes to numerous means to endorse the images of an organization. The purpose of this study is to propose a comprehensive model to evaluate the performance of Public Relations at universities. This study follows both the quantitative and qualitative research methodology and reveals that the practice of public relations at the universities in Bangladesh is not up to the mark; even in many universities, it does not have any existence. The universities which have been practising it still have a lack of manpower, inadequate infrastructure, insufficient modern equipment and technology, unsatisfactory support from the concerned authorities and, budget scanty. In this backdrop, this study shows a significant positive relation of the independent variable to PR performance (independent variables $\mathrm{p}<0.5$ ) and establish a model to evaluate public relations practice in the universities.
\end{abstract}

Keywords: Public Relations, Bangladesh, University Level, Performance Evaluation, Mixed Method

\section{Introduction}

Public Relations is the official spokespersons of any institutions that build rapport with various entities like clients, customers, stockholders, employees and any other persons (Harlow, 1976; Hutton, 1999; Verčič et al., 2001). It is not limited simply to increase awareness about an organization, rather it deals with other complex functions of checking and monitoring the reactions of its activities (Ahluwalia et al., 2000). The primary motive of this is to provide a communication channel between an organization and its users. It is a way to identify, establish and maintain mutually beneficial relationships among the organizations (Gordon, 1997; Hutton et al., 2001). Prior to the development of information technology, it has a limited scope but now a day the advent of new technology increases the latitude of public relations grossly to disseminate news and to interconnect with larger segments of the population (Hannay and McGinn, 1980; Johnson, 1997; Hill and White, 2000).

However, in Bangladesh, the practice of public relations has started soon after its independence in 1971 (Ullah, 2008; Mahmud and Nasreen, 2009). The government of Bangladesh established the Department of Mass Communication (DMC) in 1972 to disseminate information to the people through print and electronic media (The Government of the Peoples Republic of Bangladesh, 2017). Later, National Institute of Mass Communication (NIMC) was established in 1980 which works persistently in developing trained and skilled manpower in the field of print, electronic, audio and video media (National Institute of Mass Communication, 2018). Meanwhile, the pioneer organization in this esteem, Bangladesh Public Relations Association (BPRA) was inaugurated in the year of 1979 and a first national convention was held in the same year (Genilo et al., 2011). Moreover, the Ministry of Information established in December 1982 as a directory to increase the professional skills of the government, semi-government, autonomous organizations and public relations officers of the corporation and strengthen the public relations activities (National Institute of Mass Communication, 2018). Currently, the Press Information Department (PID) under the Ministry of Information works as a bridge between people and the Government. It releases news and pictures of the Government as the only authentic source of the Government of Bangladesh (Alam, 2014a). The mottos of these activities are to collect people's feedback so that the concerned ministries could take people-friendly policies. 
On the other hand, Press Institute of Bangladesh (PIB), established in 1976 as an autonomous national research institute that provides training to journalists and carries out research on mass media and journalism (The Government of the People's Republic of Bangladesh, 2018). Since 1993 the use of internet adds a pace in communication. Following this time, many governments, semi-government, autonomous and nongovernmental organizations have established their own information-rich website for effective and transparent public relations. The Government of Bangladesh has instructed its departments and ministries to launch PR programs by utilizing the existing media and resource support. Based on this stimulating demand, now along with public universities some private universities also provided degrees on journalism. This study will help the authority to establish a full-fledged PR section at different universities in Bangladesh. Indeed, it will establish a performance measurement model of PR in Bangladesh.

\section{Literature Review}

There are avalanches of literature on Public Relations and its various impacts on the organization. Many books, research articles and reports have been written on this topic, which presents different aspects of Public Relation. In the literature, it has seen that the scope of public relation has increased with the advent of modern technology. It has contributed to upholding the image of an organization by providing various feedbacks on related issues.

Ibrahim (2017), a professor of Egypt, discussed in his article that some officials of Federation International de Football Federation (FIFA) arrested by Swiss authorities due to a corruption crisis that effects on their reputation. Following this incident, the relationship between FIFA with their stakeholders abruptly fall and the partners show less interest to renew the contact further. He has mentioned that FIFA followed 'Deny Strategy' and used mass media to manage the crisis. They sent a press release, an organized press conference to make few statements through media. Thus FIFA retrieved its reputation gradually. Onsongo (2017) professors from the University of Rwanda, discussed the contribution of Public Relation practice to organizational effectiveness in private universities in Rwanda. The authors found the high impact of PR on organizational effectiveness. The authors recommended the enhancement of PR practice in private universities to the excellent standards in order to facilitate $P R$ to have a real contribution to the effectiveness of the institutions. He argues that excellence theory is more effective and specific which help the organization to achieve its goals.

Tengilimoglu (2007) presents that public relations activities help consumers to make their decisions in
Turkey. The authors argue that because of an increasing number of service providers, the consumers get confused where they can get a better service. The authors conducted this study on 971 patients and found public relations activities are needed to inform the patients to choice hospitals services. Geçikli (2014), a public relations specialist in Turkey, mentioned in her article the importance of the public relations department in the hospital and she presented a model on it. She argues that the service quality of hospitals is one of the key indicators and the citizens' demand with the possible lowest cost service but the patients do not know ins and outs about the health service, so public relations department is needed.

Shamsan (2015) discuss in their article about the importance of strategic Public Relations to take out an organizational goal. Authors conducted this study on Red Cross Kenya by using primary data. They stated that once the Kenya Red Cross Society experienced calamities and disasters in Kenya, Strategic Public Relations helped to overcome this crisis. Omondi (2006) discussed the Public Relation practice in Kenya has a high impact on the government and its various departments as the modern government used this tool to explain and implement policies. He also states that the government used Public Relation to publicize news in order to ensure good governance. Petrovici (2014) says that in the era of web 2.0, the public relation has evolved as PR 2.0. He also stated that PR deals with the human relationship so EPR has great potential. He says at this age, it is certainly possible to maintain PR activities in various ways and even it facilitates two-way communication. Grunig (2009) says that the present age made the Public Relation Profession more global, two-way and interactive. Practitioners use new media as the old media.

Dimitrakopoulou (2015) presents that the role of social media in Tourism and Hospitality Industry has increased because now visitors conduct everything through online like booking and observe the rating to visit that by changing traditional PR techniques. Now social media affects the customers to take the decision analyzing everything by social media. Public Relations got the new and effective scope to present reputational aspects by dint of social media easily. People, before the visit, rely on social media for getting accurate information.

Mass media occupy an important place in contemporary society. In his study, Macnamara (1993) has explained four models of PR. Besides, he clearly defines Public Relation in his study. Gilaninia et al. (2013) discuss three types of duties of PR: Informing, advertising and encourage and seeking cooperation, integration and optimizing affairs. They say that now the world is based on communication technology and millions of information units are exchanged in every 
second so people with more information will be more successful. Public relation becomes direct communication techniques for communication technology. The above-discussed literature depicts various aspects of public relations and its practice such as PR in a crisis moment, how new technology changes the pattern of PR. Still, there is no research work has been conducted on the challenges of PR at different universities in Bangladesh. Thus, there remains a research gap in this particular segment of the study. This study, if taken into consideration, will meet the research gap and help to diagnose the problems more specifically.

\section{Methodology}

This study follows a mixed-method approach, where both quantitative and qualitative data have been used. Through a mixed method, a triangulation process consists of theoretical propositions, qualitative findings and quantitative findings are estimated. Three types of triangulation findings (complementary, convergent and divergent) are identified in the literature. To construct a single proposition, we have applied the convergent triangular process in this study through theories and empirical results of qualitative and quantitative data (Östlund et al., 2011). The data of this study have been collected from both the primary and secondary sources. The primary data has been collected from the public relations officials at various universities in Bangladesh. Under a convenient sampling method, we have taken ten different universities namely; Bangladesh University of Professionals, Jahangirnagar University, United International University, Daffodil International University, Comilla University, Bangabandhu Sheikh
Mujib Maritime University, Stamford University, University of Liberal Arts Bangladesh, University of Development Alternative and Bangladesh University of Business and Technology.

Using a purposive sampling method, we have conducted a survey through Google doc and conducted two Key Informant Interviews (KIIs). The survey questionnaire was designed with five-point liker type questions (Strongly Agree, Agree, Neutral, Disagree and Strongly Disagree). Finally, the questionnaire converted into Google Docs and sent to the respondents through Facebook groups and to the respondents' personal email. To analyze the data, we have used ANOVA analysis in IBM SPSS 22.

On the other hand, qualitative data (KIIs and FGD) are intuitively analyzed with the perceptions of the respondents under the content analysis method. We have summarized this information and matched them with the quantitative part. Rational information is gathered and tabulated in a merged form of the study. Finally, these outputs are logically figured out the main objectives of the study. Thus, the amalgamation of literature review (theory), qualitative data and quantitative data have portrayed the total outcome of the research under convergent type mixed method. Finally, at the time of data collection, the authors' field of research lacked an appropriate institutional and/or national research committee to which the protocols adopted in the study could be referred. Nevertheless, the authors took care to ensure that the procedures performed in the study were conducted in alignment with international ethical standards, in particular, the EU's ESRC framework for research ethics in the social sciences. The following Table 1 depicts the demographic profile of the respondents.

Table 1: Demographic profile of the respondents

\begin{tabular}{llc}
\hline Criteria & Frequency (n) & Percentage (\%) \\
\hline Gender & 24 & 80 \\
Male & 06 & 20 \\
Female & & 20 \\
Age & 06 & 30 \\
$20-30$ & 09 & 50 \\
$31-40$ & 15 & 100 \\
$41-50$ & & 40 \\
Education & 30 & 60 \\
Post Graduate & & \\
Type of Institution & 12 & 40 \\
Public University & 18 & 10 \\
Private University & & 30 \\
Year of Experience & 12 & 20 \\
Less than 5 & 03 & \\
5-10 & 09 & \\
$11-15$ & 06 & \\
16 and above & &
\end{tabular}

Source: Survey Result of this Study 
Besides the time and fund limitations, we have found the respondents of this study were bit sceptical while sharing their information. However, we have taken ethical permission and assured the confidentiality of the information. For the secondary sources, we have analyzed research articles, books, reports and related websites.

\section{Operational Definition}

\section{Public Relation}

Public Relations is a way which helps an organization or an individual to maintain communication with other people, thus it develops resonance between target community and institution and sustains the efforts to keep this resonance (Dominick, 1996; Omondi, 2006). On the other hand, it is a strategic communication process that helps to create mutually beneficial relationships between organizations and their people which play a fundamental role in the success and failure of an institution (Kent and Taylor, 2002). It aims to create, maintain and protect the organization's reputation, enhance its status and denote a favourable image (Wilcox et al., 2006). Newsletter, Press Release, Brochure, Social Media and Press Conference are the tools of PR. Now a day the social media has also been considered as the most powerful tool of PR (Alam, 2014b). However, PR for this study refers to the activities and practice of public relations wing at the universities in Bangladesh.

\section{Prevailing State of PR Performance at Universities in Bangladesh}

This study reveals a lack of sufficient infrastructural facilities such as the computer, high-resolution video camera, internet facilities, printing facilities of its own. Budgetary allocation for printing and publications still remain at a marginal level. This study also found a lack of manpower in comparison to workload. It has also been evolved that in some universities the clerk or MLSS works as a cameraman and covers numerous seminars and workshops (M. Islam, personal communication, March 27, 2018). In most of the cases, the authority fails to demonstrate the job responsibility of PR officials (E. Islam, personal communication, June 05, 2018). It also has known that most of the PR officials at different universities do not have adequate PR related degrees and professional training.

The Fig. 1 clearly demonstrates that $10 \%$ of respondents believe that their PR activities are standard and $26.7 \%$ of the respondents thought it is moderately standard. However, the rest of the $63.3 \%$ of the respondents viewed their activities as traditional, not standard or remain the same. From this data, it can easily be concluded that the PR activities at universities in Bangladesh remain to some extent in the lower standard.

Fig. 2 clearly shows that private universities are more satisfied over their PR infrastructure and practice rather than public universities. This study found that most of the private universities are giving their highest priority on the PR office. The private universities in having to advertise their project and offer to draw the attention of the people and to get more students. Public universities, on the other hand, do not have to do so. The following case study will clearly demonstrate the scenario of PR at public universities in Bangladesh.

\section{Case Study: Jahangirnagar University}

Jahangirnagar University has started its activities in 1972, is the only completely residential university of Bangladesh. There are four institutes and six faculties including arts and humanities, mathematical and physics, social science, biological science, business studies and law faculty in this university. Thus, the PR branch has a substantial role in advocating all the faculties, departments and institutes of the country's largest university. But the lack of adequate manpower in this section is noticeable. Although there is considerable importance for information technology in modern PR management, it has been found that there are only two computers for five officers in the PR office. There are also no cameras for casting different event videos. There are cameras to take pictures, but it is not that's good quality. And there is no skilled manpower in these jobs. Also, the social media connectivity of the PR office of this university cannot be seen. In addition to these infrastructural weaknesses, the PR officials need to face various types of institutional and non-institutional challenges in the field of personal crossover, lack of professionalism by higher authorities, obstructing their regular work. In some cases, it is also seen that, in addition to other additional courses, including the evening course of this university, where advertising is important work, the PR is in no way relieving the responsibilities and the concerned departments contact directly to the advertising authority directly from their respective departments or faculty. As a result, the prestige and institutional power of the PR are diminishing. In some cases, it is seen that people who do not have pre-experience or institutional knowledge in the field of PR are also monitoring these issues at various times, which has resulted in a dispute with officials at different times.
(Sources: Observation and Personal Communication, 29 March 2018) 


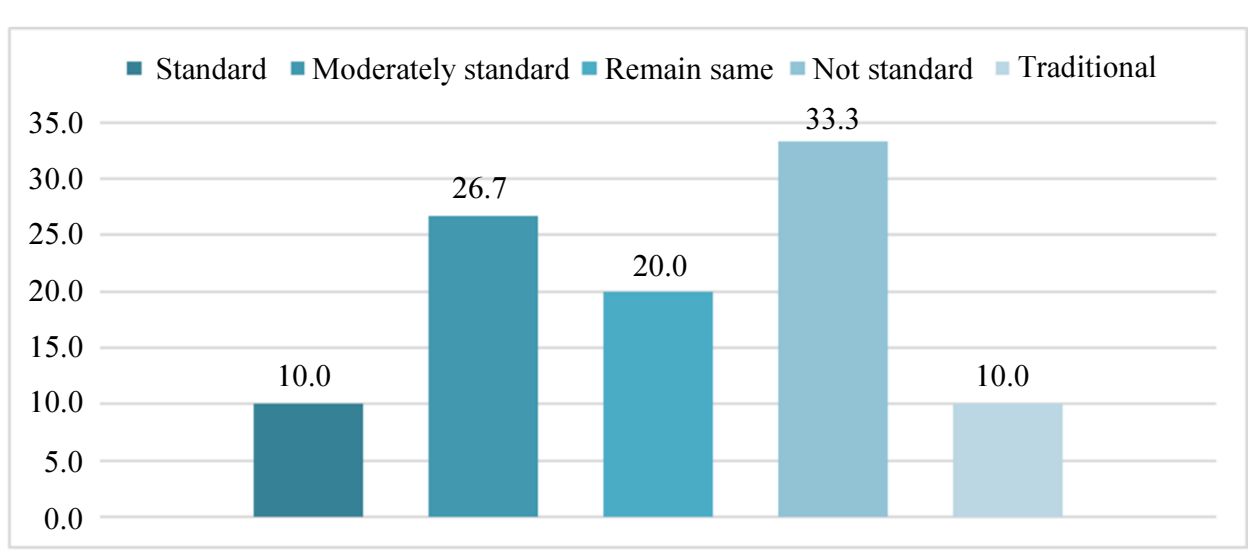

Fig. 1: Prevailing standard of PR activities at the universities

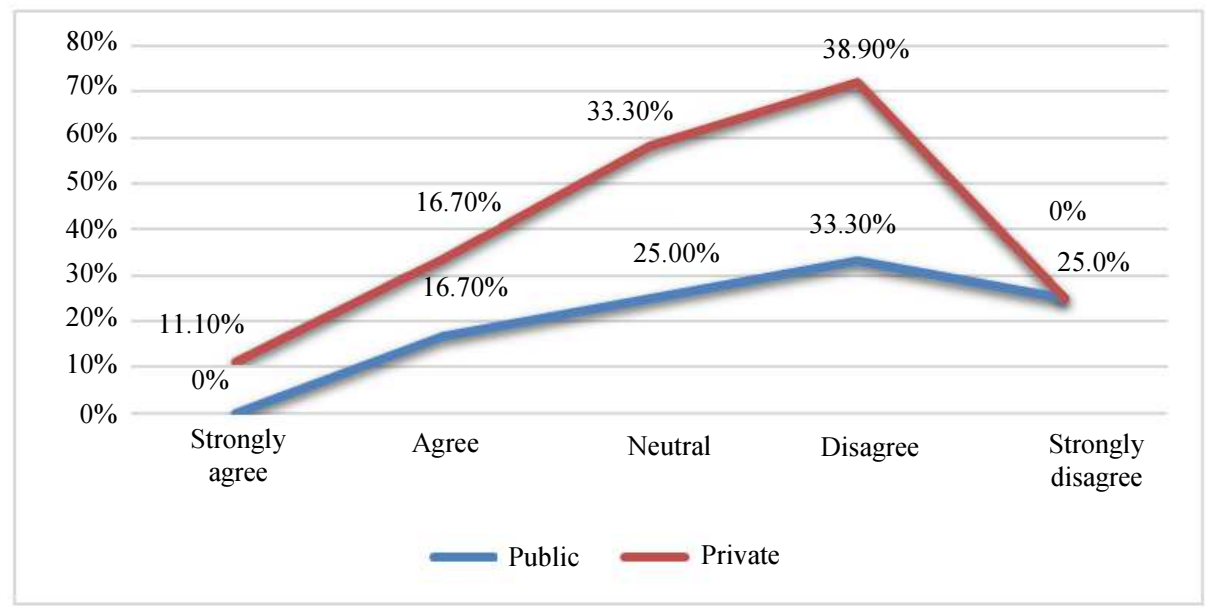

Fig. 2: Satisfaction over infrastructural facilities at public and private universities

\section{Public Relations Performance Evaluation (PRPE) Model}

In this backdrop, this study uses a revised model to evaluate the public relations practice at the universities in Bangladesh. Shamsan (2015) in their study grounded the indicators to evaluate the performance of public relations. We have incorporated some other indicators based on the real-life experience and country-specific orientation. The following Fig. 3 clearly illustrate the proposed Public Relations Practice Evaluation (PRPE) Model of this study.

In this model the dependent public relations performance largely depends on five independent variables, these are infrastructural capabilities, financial allocation, human resource, man expertise and last but not the least the authority support.

\section{Reliability Test}

In order to determine if the survey questions were consistently giving reliable results, Cronbach's Alpha value for the overall measure and each scale is the widely used reliability measurement. The commonly used threshold of $\alpha=0.70$ (Hair et al., 1995) was employed to evaluate the scales. Here, after considering the total 29 items, it is found that the value of Cronbach Alpha coefficient of internal consistency is 0.937 . In addition, a reliability analysis was then run for each of the five scales separately. The reliability for each of the scales was either approaching or above the accepted value with $\alpha=0.798$ for infrastructural capacity, $\alpha=0.818$ for human resource, $\alpha=0.702$ for man expertise, $\alpha=0.893$ for budget and $\alpha=0.862$ for support from the authority. Convergent validity is the degree where several items were employed to measure a specific construct (Wong, 2013). According to them, convergent validity was measured based on assessing the factor loading, Average Variance Extracted (AVE) and Composite Reliability (CR). AVE and CR were considered 0.50 and 0.70 . Composite reliability should be greater than the benchmark of 0.7 to be considered adequate. 


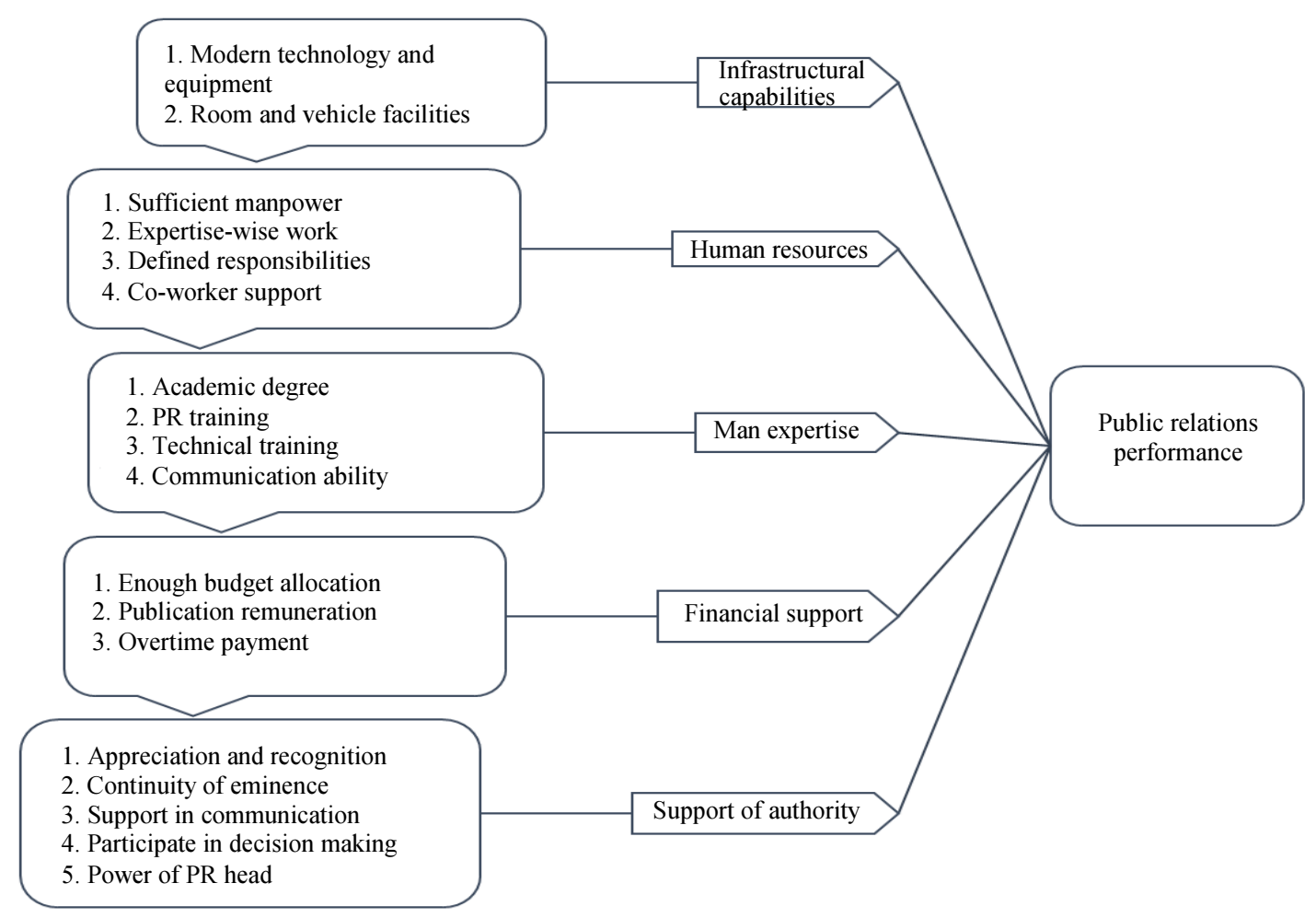

Fig. 3: Public Relations Performance Evaluation (PRPE) model

In Table 2, each value has come above the benchmark except two. Another parameter for measuring convergent validity was the Average Variance Extracted (AVE) which means the sum of the squared loadings divided by the number of indicators which is equivalent to the commonality to the construct. AVE for each construct exceeded the accepted threshold of 0.5 . The AVE for each factor was more than 0.5 which further ensured convergent validity. In Structural Equation Modeling, for the convergent validity, the factor loadings and AVE should be greater than 0.5. Therefore, the convergent validity for all the assigned constructs was justified and verified.

With the help of the Exploratory Factor Analysis (EFA) techniques, the loading and internal reliability of constructs using Cronbach Alpha coefficient were tested (Table 3). Based on the result, it has seen to be deleted some items because factor loading less than. 50 did not consider/reproduce. Highest loading indicates the relative significance of the items that were used to build up the respective construct.

\section{Hypothesis Test}

The hypothesis has been conceptualized based on the literature reviews and practical experiences, this section of the study will test the significance of the hypothesis.

\section{Hypothesis 1}

$\mathrm{H}_{0}$ : PR performance does not rely on infrastructural capabilities

$\mathrm{H}_{\mathrm{a}}$ : PR Performance relies on infrastructural capabilities

\section{Hypothesis 2}

$\mathrm{H}_{0}$ : Human resources do not have any relation to the PR performance

$\mathrm{H}_{\mathrm{a}}$ : Human resource is positively related to $\mathrm{PR}$ performance

\section{Hypothesis 3}

$\mathrm{H}_{0}$ : Expertise man does not play any role in the PR performance

$\mathrm{H}_{\mathrm{a}}$ : Expertise man plays a significant role in the PR performance

\section{Hypothesis 4}

$\mathrm{H}_{0}$ : Budgetary allocation is not essential to conduct the PR activities

$\mathrm{H}_{\mathrm{a}}$ : Budgetary allocation influences to conducting the PR activities

\section{Hypothesis 5}

$\mathrm{H}_{0}$ : Authority support is not essential to conduct the PR activities 
$\mathrm{H}_{\mathrm{a}}$ : Authority support influences to conducting the PR activities

In the current study, the dependent variable is public relations performance. The correlation analysis reveals that all variables are positively correlated with public relations performance. Among these four variables are strongly correlated and only one variable is moderately correlated. The result of the analysis reveals that these have a significant positive relation to PR performance. It has found in Table 4 that infrastructural capabilities and PR performance $(\beta=0.749, \mathrm{p}<0.5)$, human resource and PR performance is $(\beta=0.777, \mathrm{p}<0.5)$, man expertise and PR performance $(\beta=0.526, \mathrm{p}<0.5)$, budgetary allocation and PR performance $(\beta=0.606, \mathrm{p}<0.5)$ and authority support and PR performance $(\beta=0.776, \mathrm{p}<0.5)$.

In Table 5 the p-value has been found less than 0.05 . That means the null hypothesis may be rejected at $5 \%$ level of significance. So, it can be concluded that infrastructure facilities have a positive impact on the performance of the Public Relations Office.
In Table 6 the p-value has been found less than 0.05 . That means the null hypothesis may be rejected at $5 \%$ level of significance. So, it can be concluded that human resources have a positive impact on the performance of Public Relations.

In Table 7 the p-value has been found less than 0.05 . That means the null hypothesis may be rejected at $5 \%$ level of significance. So, it can be concluded that the budgetary allocation support plays a significant role in the performance of the Public Relations Office.

In Table 8 the p-value has been found less than 0.05 . That means the null hypothesis may be rejected at 5\% level of significance. So, it can be concluded that the support from authority plays a significant role in the performance of the Public Relations Office.

In Table 9 the p-value has been found less than 0.05 . That means the null hypothesis may be rejected at 5\% level of significance. So, it can be concluded that the expert manpower plays a significant role in the performance of the Public Relations Office.

Table 2: Convergent Validity of the Scale

\begin{tabular}{llll}
\hline Name of the Factor & Cronbach's Alpha & Composite Reliability & Average Variance Extracted (AVE) \\
\hline Infrastructure & 0.798 & 0.887807 & 0.500399 \\
Human Resource & 0.818 & 0.503411 & 0.895305 \\
Man Expertise & 0.702 & 0.85911 & 0.604729 \\
Authority Support & 0.862 & 0.757633 & 0.925802 \\
Budget & 0.893 & 0.469466 & 0.885512 \\
\hline
\end{tabular}

Table 3: Rotated component matrix

\begin{tabular}{|c|c|c|c|c|c|c|}
\hline Components & Items & Factor 1 & Factor 2 & Factor 3 & Factor 4 & Factor 5 \\
\hline \multirow[t]{5}{*}{ Infrastructure Capabilities } & Computer facilities & 0.773 & & & & \\
\hline & Camera facilities & 0.554 & & & & \\
\hline & Video camera & 0.914 & & & & \\
\hline & Vehicle facilities & 0.918 & & & & \\
\hline & Printing facilities & 0.719 & & & & \\
\hline \multirow[t]{5}{*}{ Human Resources } & Sufficient manpower & & 0.812 & & & \\
\hline & Expertise based work distribution & & 0.589 & & & \\
\hline & Job responsibility & & 0.786 & & & \\
\hline & Freedom of work & & 0.878 & & & \\
\hline & Co-worker support & & 0.884 & & & \\
\hline \multirow[t]{4}{*}{ Man Expertise } & Academic degree & & & 0.697 & & \\
\hline & PR related training & & & 0.789 & & \\
\hline & Communication ability & & & 0.811 & & \\
\hline & PR training in foreign & & & 0.808 & & \\
\hline \multirow[t]{4}{*}{ Budgetary Allocation } & Budget for equipment & & & & 0.938 & \\
\hline & Remuneration for publication & & & & 0.837 & \\
\hline & Overtime & & & & 0.854 & \\
\hline & Budget for publication & & & & 0.849 & \\
\hline \multirow[t]{5}{*}{ Authority Support } & Appreciation and recognition & & & & & 0.841 \\
\hline & Support in Communication & & & & & 0.734 \\
\hline & Participate in Decision making & & & & & 0.649 \\
\hline & PR head attending at decision making & & & & & 0.733 \\
\hline & Time viable initiative & & & & & 0.922 \\
\hline
\end{tabular}

*Note: Factor loading less than 0.50 have not been considered/reproduced 
Table 4: Results of the hypothesis

\begin{tabular}{|c|c|c|c|c|c|}
\hline Path & Value of $r$ & Standardized coefficients $(\beta)$ & t Statistic & P-value & Decision \\
\hline Infrastructural capabilities $>$ PR performance & 0.749 & 0.749 & 5.989 & 0.000 & Significant \\
\hline Human resource $>$ PR performance & 0.777 & 0.777 & 6.525 & 0.000 & Significant \\
\hline Man expertise $>$ PR performance & 0.526 & 0.526 & 3.273 & 0.003 & Significant \\
\hline Budgetary allocation $>$ PR performance & 0.606 & 0.606 & 4.027 & 0.000 & Significant \\
\hline Authority support $>$ PR performance & 0.776 & 0.776 & 6.517 & 0.000 & Significant \\
\hline
\end{tabular}

Table 5: Significance test $\left(\mathrm{ANOVA}^{\mathrm{a}}\right)$

\begin{tabular}{llllll}
\hline Model & Sum of squares & df & Mean square & F & Sig. \\
\hline Regression & 23.511 & 1 & 23.511 & 35.865 & $0.000 \mathrm{~b}$ \\
Residual & 18.355 & 28 & 0.656 & & \\
Total & 41.867 & 29 & & & \\
\hline
\end{tabular}

a. Dependent Variable: PR activities is a high standard in this organization

b. Predictors: (Constant), Infrastructure facilities

Table 6: Significance test (ANOVA ${ }^{\mathrm{a}}$ )

\begin{tabular}{llllll}
\hline Model & Sum of Squares & df & Mean Square & F & Sig. \\
\hline Regression & 25.257 & 1 & 25.257 & 42.578 & $0.000 \mathrm{~b}$ \\
Residual & 16.610 & 28 & 0.593 & & \\
Total & 41.867 & 29 & & & \\
\hline
\end{tabular}

a. Dependent Variable: PR activities is a high standard in this organization

b. Predictors: (Constant), Human Resources

Table 7: Significance test (ANOVA ${ }^{\mathrm{a}}$ )

\begin{tabular}{llllll}
\hline Model & Sum of squares & df & Mean square & F & Sig. \\
\hline Regression & 11.587 & 1 & 11.587 & 10.714 & $0.003^{\text {b }}$ \\
Residual & 30.280 & 28 & 1.081 & & \\
Total & 41.867 & 29 & & & \\
\hline
\end{tabular}

a. Dependent Variable: PR activities is a high standard in this organization

b. Predictors: (Constant), Man Expertise

Table 8: Significance test (ANOVA ${ }^{\mathrm{a}}$ )

\begin{tabular}{llrrrl}
\hline Model & Sum of squares & df & Mean Square & F & Sig. \\
\hline Regression & 15.357 & 1 & 15.357 & 16.220 & $0.000^{b}$ \\
Residual & 26.510 & 28 & 0.947 & & \\
Total & 41.867 & 29 & & & \\
\hline
\end{tabular}

a. Dependent Variable: PR activities is a high standard in this organization

b. Predictors: (Constant), Budgetary allocation

Table 9: Significance test (ANOVA ${ }^{\mathrm{a}}$ )

\begin{tabular}{llrrrl}
\hline Model & Sum of squares & df & Mean Square & F & Sig. \\
\hline Regression & 25.233 & 1 & 25.233 & 42.475 & $0.000^{b}$ \\
Residual & 16.634 & 28 & 0.594 & & \\
Total & 41.867 & 29 & & & \\
\hline
\end{tabular}

a. Dependent Variable: PR activities is a high standard in this organization

b. Predictors: (Constant), Support from Authority

\section{Conclusion}

This paper develops a theoretical perspective for measuring the performance of public relations. The findings and the results of the study reject the null hypothesis and established that the performance of PR largely depends on its infrastructural capabilities, strong human resources, expertise, proper financial support and finally the support from the concerned authority. This study has investigated the aspect of public relations practice in various universities of Bangladesh and identified numerous deficiencies that influence their performance. This study divulges that the PR at most of the universities in Bangladesh has been going through some challenges such as the lack of infrastructural facilities, unsatisfactory monetary allocation, amateurish manpower, unnecessary interloping. In many cases, it is noticed that the higher authority of many universities does not sufficiently emphasis on this particular office. To foster the public relations practice at universities the 
concerned authorities should have taken adequate measures. The modern electronic devices such as the computer, high-resolution video cameras, still image cameras, high-speed internet service need to arrange in every PR office. The authority needs to recruit sufficient manpower from different categories, such as graphic designer, cameraman, video man, social media expert, public relations expert, publications expert etc. Arranging training for the newly recruited officials is also mandatory to let them know what their individual job responsibilities in the office. For the old age officials, it is mandatory to arrange training on modern information technologies at home and if possible abroad. However, a study on the training need assessment will highly be appreciated.

\section{Author's Contributions}

All authors are contributed equally. The authors declare that they have no conflict of interest.

\section{Ethics}

At the time of data collection, the authors' field of research lacked an appropriate institutional and/or national research committee to which the protocols adopted in the study could be referred. Nevertheless, the authors took care to ensure that the procedures performed in the study were conducted in alignment with international ethical standards, in particular the EU's ESRC framework for research ethics in the social sciences. Moreover, Informed consent was obtained verbally from all individual participants included in the study.

\section{References}

Ahluwalia, R., R.E. Burnkrant and H.R. Unnava, 2000. Consumer response to negative publicity: The moderating role of commitment. J. Market. Res., 27: 203-214.

Alam, M., 2014a. Public Relations. 1st Edn., Bangladesh Asiatic Society, Banglapedia, Dhaka.

Alam, D.H., 2014b. Social media as a tool of resistance and counter-power: A critical look to Facebook on the issue of communal attack at Ramu. Soc. Sci. Rev., 31: 1-15.

Dimitrakopoulou, K., 2015. Public relations in the tourism industry: The growing role of social media. $\mathrm{PhD}$ Thesis, American College of Greece.

Dominick, R.J., 1996. The Dynamics of Mass Communications. 1st Edn., Mc Graw Hill, New York.

Geçikli, F., 2014. The organization of public relations department at hospitals: A model suggestion. Int. J. Bus., Humanit. Technol., 96: 51-59.

Genilo, J.W., M. Akther and I.A. Chowdhury, 2011. A survey of public relations practice in Bangladesh. Media Asia, 38: 191-191.
Gilaninia, S., M. Taleghani and M.E. Mohammadi, 2013. The role of public relations in organization \nigerian chapter of Arabian. J. Bus. Manage. Rev., 1: 60-96.

Gordon, J.C., 1997. Interpreting definitions of public relations: Self-assessment and a symbolic interactionism-based alternative. Public Relat. Rev., 23: 57-66.

Grunig, J.E., 2009. Paradigms of global public relations in an age of digitalisation. Prism, 6: 56-59.

Hair, J., R. Anderson and R.C. Tatham, 1995. Multivariate Data Analysis with Readings. 1st Edn., Prentice-Hall, New Jersey.

Hannay, N.B. and R.E. McGinn, 1980. The anatomy of modern technology: Prolegomenon to an improved public policy for the social management of technology. Daedalus, 54: 25-53.

Harlow, R.F., 1976. Building a public relations definition. Public Relat. Rev., 2: 34-42.

Hill, L.N. and C. White, 2000. Public relations practitioners' perception of the worldwide web as a communications tool. Public Relat. Rev., 26: 31-51.

Hutton, J.G., 1999. The definition, dimensions and domain of public relations. Public Relat. Rev., 25: 199-214.

Hutton, J.G., M.B. Goodman, J.B. Alexander and C.M. Genest, 2001. Reputation management: The new face of corporate public relations? Public Relat. Rev., 27: 247-261.

Ibrahim, L.A., 2017. Managing the reputation of the Federation Internationale de Football Association (FIFA): The case of the corruption crisis. Public Relat. J., 49: 1-18.

Johnson, M.A., 1997. Public relations and technology: Practitioner perspectives. J. Public Relat. Res., 9: 213-236.

Kent, M.L. and M. Taylor, 2002. Toward a dialogic theory of public relations. Public Relat. Rev., 28: 21-37.

Macnamara, J., 1993. Public relations and the media: A new influence in 'agenda-setting' and content. Deakin University, Australia.

Mahmud, S. and G. Nasreen, 2009. Net switching in journalism education in Bangladesh: Problems and prospects. J. Asiatic Soc. Bangladesh, 54: 1-19.

Omondi, M.O., 2006. The performance of public relations practice in government ministries in Kenya: A critic analysis.

Onsongo, A.N.D.H., 2017. The contribution of public relations practice to organizational effectiveness: A case of private universities in Rwanda. Int. J. Comput. Sci. Technol., 8: 155-169. 
Östlund, U., L. Kidd, Y. Wengström and N. RowaDewar, 2011. Combining qualitative and quantitative research within mixed method research designs: A methodological review. Int. J. Nurs. Stud., 48: 369-389.

DOI: 10.1016/J.IJNURSTU.2010.10.005

Petrovici, M.A., 2014. E- Public Relations: Impact and efficiency: A case study. Procedia-Soc. Behav. Sci., 141: 79-84.

Shamsan, R.M.D.M., 2015. Effects of strategic public relations on organization performance: A Case Study of Kenya red cross society. Int. J. Sci. Res. Publicat., 5: 1-12.

Tengilimoglu, D.P.M., 2007. The role of public relations activities in hospital choice. Health Market. Quarterly, 89: 19-31.

The Government of the Peoples Republic of Bangladesh, 2017. Ministry of Information. Bangladesh National Portal.
The government of the People's Republic of Bangladesh, 2018. Press Institute Bangladesh. Bangladesh National Portal.

Ullah, M.S., 2008. Scholarly turn of journalism education: Redesigning curricula at the university level in Bangladesh. J. Global Commun., 1: 1-13.

Verčič, D., B. Van Ruler, G. Bütschi and B. Flodin, 2001. On the definition of public relations: A European view. Public Relat. Rev., 27: 373-387.

Wilcox, D.L., P.H. Ault and W.K. Agee, 2006. Public relations: Strategies and tactics.

Wong, K.K., 2013. Partial Least Squares Structural Equation Modelling (PLS-SEM), techniques using SmartPLS, Marketing Bulletin, Technical Note 1.

\section{Figure Source}

(Source: revised from Shamsan, 2015) 